\title{
Stress Experiences and Reactions of University Students Studying in the Education Faculties
}

\author{
Behiye Akacan \\ European University of Lefke, N. CYPRUS
}

Received 12 June 2017 - Revised 17 August 2017 - Accepted 16 September 2017

\begin{abstract}
The aim of this research is to analyse the reactions of university students in situations where they experience stress in order to create a psychological counselling program with a group based on Rational Emotional, Behavioural, Cognitive and Existential Approaches in order to improve the ability of first year students studying in the Counselling and Psychological Guidance and Preschool Teaching Department to cope with stress. The study examined the behaviours and thoughts of students in the context of these reactions as to the situations in which they experienced and believed to experience stress. In the study, face-to-face interviews were conducted on 45 students in the Counselling and Psychological Guidance and Pre-School Teaching Departments by using the semistructured interview form developed by the researcher. Data were collected on the perceptions and the stress experienced or believed to be experienced by the interviewed university students, who formed the study group, and their thoughts and behaviours in line with these cases. The data obtained from the interviews were analysed by content analysis. It has been revealed that the first year students in Guidance and Psychological Counselling and Preschool Teaching Departments usually produced negative thoughts against the stress experienced within the university life and their behaviours appeared in the form of falling academic performance and avoidance in social relations.
\end{abstract}

Keywords: university students, stress, group counselling

\section{INTRODUCTION}

Stress is the reaction individuals show against a situation of difficulty that they meet at every stage of their lives. While these reactions may emerge in a variety of situations, stress often manifests itself as a condition that individuals often meet in their daily and school lives. Nowadays, it is seen that every individual encounters the concept of stress and it became a part of their daily life.

The inevitable self-imposed stress at any moment in the individuals' lives can be controlled and managed with developed coping strategies. Stress appears as a part of human life while gradually becoming a difficult situation to survive from within life, but it deeply affects the individuals' lives. Individuals need to raise consciousness at a certain rate towards the concept of stress so that they can continue to live their daily lives better.

While stress is perceived as a negative situation in individuals' daily lives of individuals, Rojas and Kleiner (2000) emphasize that stress should not always be considered negative. Güçlü (2001) describes this situation as the problems brought about by various economic, social and technological changes that the individual faces in everyday life. According to Deniz and Yilmaz (2005), stress is expressed as a concept stemming from the incompatible relationship between individual and environment.

(C) Authors. Terms and conditions of Creative Commons Attribution 4.0 International (CC BY 4.0) apply. Correspondence: Behiye Akacan, Dr. Fazıl Kucuk Education Faculty, European University of Lefke, Lefke, Cyprus. $\triangle$ behiyeakacan@hotmail.com 


\section{State of the literature}

- The concept of stress is a situation to be encountered by individuals throughout their life and they need to be aware of these stressful situations.

- Thoughts and behaviours of individuals experiencing stress are significant determinants for practitioners.

- Stress is caused by negative thoughts like being unsuccessful, insufficient performance in lectures and uncertainty after graduation, being afraid of inability of finding jobs and lack of professional information.

\section{Contribution of this paper to the literature}

- It can be derived from the results that university students experience stress in case of adapting to the university environment, family estrangement and failure to meet expectations from university environment

- Helping university students to coping with stressful situations depends on the implementation of psychological counselling programs

- This research has been conducted in order to determine the variables causing stress in the life of university students.

Stress can be defined as the factors that cause distress, anxiety and tension in individual's life and academic activities for university students. Dyson and Renk (2006) state that the adaptation problems experienced by university students in the daily and academic life put stress on students. As is known, the university period is referred to as a new period in individual's life and is a period of significant development in the process of acquiring many new experiences in many academic, social and personal terms and preparing for a career. In this period, university students are expected to deal with many issues such as adapting to the academic and social environment and meeting academic expectations. In line with these expectations, students will face a certain level of stress while adapting to the new university environment and building new friendships as well as carrying out career planning studies. In this context, university students should be able to cope with the stress situation they face.

As is known, the role of the teacher in the teaching process is highly significant that it cannot be denied. This is because the process of being successful in the educational process depends entirely on the success of the teacher. Therefore, the encountering of students trained to work in the fields of teaching and psychological assistance with the concept of stress does not only threaten their academic success but also their adaptation to their future professional life. Thus, it is highly important that the factors that cause the stress in life are determined at the earliest time and the individuals learn to cope with the stress they experience.

\section{METHODOLOGY}

\section{Research Pattern}

This research is a qualitative research. In the study, semi-structured interview technique was used as qualitative research methods.

\section{Universe and Sampling}

The participants of the research were a total of 45 students studying in the first year of the Guidance and Psychological Counselling (GPC) and Pre-School Teaching (PST) Departments in the Lefke European University in the fall term of the 2016-17 academic year.

\section{Data Collection Tools}

Semi-structured interview form developed by the researcher was used as data collection tool in the research. By using forms, the perceptions of the interviewed university students forming the study group about the concept of stress, situations in which stress is experienced and expected to be experienced and information about their thoughts and behaviours related to these situations were collected. 


\section{Data Collection Process}

The data of the study were gathered through interviews held one day a week in the Lefke European University Faculty of Education in Lefke. In the research, approximately 25 to 45 minute interviews were held with the first-year students studying in the Counselling and Psychological Guidance and Preschool Teaching Departments in order to establish a psychological counselling program with the group to be used in the development of stress-coping skills of university students.

\section{Data Analysis}

In the data collection and analysis in the research, three main dimensions have been studied in the form of determining the situations in which students experience stress in school life and their thoughts and behaviours against these situations and the situations in which they expect to experience stress in their future professional life.

The data were collected through interviews and analysed by content analysis. In content analysis, data were analysed within three phases. The data were encoded first, and then, they were divided into specific categories. These categories include the situations in which students experience stress in university life, their related thoughts and behaviours and the situations in which they expect to experience stress in their future professional life.

\section{Findings}

The findings regarding the answers of the first-year students in Guidance and Psychological Counselling (GPC) and Pre-School Teaching (PST) Departments, interviewed in order to establish a psychological counselling program with the group to be used to develop stress coping skills in university students in the research, were categorized under the following headings:

1. Findings regarding the situations when the first-year students in GPC and PST Departments experience stress in the university lives.

2. Findings regarding the thoughts of the first-year students in GPC and PST Departments when they experience stress in the university lives.

3. Findings regarding the behaviours of the first-year students in GPC and PST Departments when they experience stress in the university lives.

4. Findings regarding the situations that the first-year students in GPC and PST Departments expect to experience stress in their future professional lives.

\section{Findings Regarding the Situations when the First Year Students in GPC and PST Departments Experience Stress in the University Lives}

The research studied 45 participants in the context of determining the situations when the university students experience stress in their university lives. The answers given by students to the question "In which situations do you experience stress in your university life?" are as follows:

1. Adaptation to university environment

2. Family estrangement

3. Failure to find expectations from university environment

4. Abandonment of past habits

The opinions of the participants were determined under the ratios and themes mentioned in Table $\mathbf{1}$ and the opinions given were presented. \%44 of participants, who are in position of GPC first year students, stated that stress is experienced by them during the adaptation situations to the university environment. "I miss my high school class a lot. I was very comfortable and peaceful in the high school environment. I used to spend nice and enjoyable time with my classmates in high school. However, I cannot spend such enjoyable time with any of my classmates in university. I cannot 
Table 1. Distribution regarding the situations when the first year students in GPC and PST Departments experience stress in the university lives

\begin{tabular}{|c|c|c|c|c|c|}
\hline & \multicolumn{2}{|c|}{ GPC Department } & \multicolumn{2}{|c|}{$\begin{array}{c}\text { PS } \\
\text { T Department }\end{array}$} & \multirow[t]{2}{*}{ Total } \\
\hline & $\mathrm{f}$ & $\%$ & $\mathbf{F}$ & $\%$ & \\
\hline Adaptation to university environment & 10 & $44 \%$ & 8 & $36 \%$ & 18 \\
\hline Family estrangement & 4 & $17 \%$ & 2 & $9 \%$ & 6 \\
\hline Failure to find expectations from university environment & 6 & $26 \%$ & 9 & $41 \%$ & 15 \\
\hline Abandonment of past habits & 3 & $13 \%$ & 3 & 14 & 6 \\
\hline Total & 23 & $51 \%$ & 22 & $49 \%$ & 45 \\
\hline
\end{tabular}

adapt to the university environment. I think this environment is very cold and frosty." The above opinions were provided by a student from the GPC Department. Having considered these explanation and opinion percentage, it can be commented that situations in which stress is experienced by the GPC first year students is in the foreground. Despite that, $36 \%$ of PST first year university students stated that the stress is experienced by them in the adaptation situations to the university environment.

$17 \%$ of GPC first grade students and 9\% of PST students stated that they experience stress in the situations of family estrangement. Regarding the question asked about determination of situations which cause stress in university life, $26 \%$ of GPC first year students and $41 \%$ of PST first year students indicated that they experience stress in situations such as failure to find expectations from university environment, university environment is very different after the high-school environment and they do not at this environment. Besides, it is seen that $13 \%$ of GPC first year students and $14 \%$ of PST first year students stated that they experience stress in situations such abandonment of past habits.

It has been found out that there are no differences between the opinions of GPC and PST students, the same view is being shared approximately and the stress is experienced in the situations of adaptation to the university environment, family estrangement, failure to find expectations from university environment and abandonment of past habits.

\section{Findings Regarding the Thoughts of the First Year Students in GPC and PST Departments when They Experience Stress in the University Lives}

The research studied 45 participants in the context of determining the situations when the university students experience stress in their university lives. The answers given by students to the question "What are your thoughts regarding the situations in which you experience stress in your university life?" are as follows:

1. Thinking to fail lessons

2. Thinking to be judged as ignorant by classmates and teachers

3. Thinking that the information to be learnt at university will not be useful for the future life

The opinions of the participants were determined under the ratios and themes mentioned in Table 2 and the opinions given were presented. The students were asked about their opinions regarding the situations in which they experience stress in the university life. $62 \%$ of the first-year student participants studying in GPC Department stated that they think they would be judged as ignorant by their classmates and teachers. "I am afraid of being judged as ignorant while performing an activity in front of my classmates." The above opinions were provided by a student from the GPC Department. Despite that, $50 \%$ of participants who are in the position of PST first year university students stated that they think they will be judged as ignorant in front of individuals and lecturers. Regarding the question asking the thoughts of the students about the situations in which they experience stress in university life, $38 \%$ of PST and 33\% of GPC first year students stated that they have negative thoughts that the information to be learnt at university will not be useful for the future life. Besides, 17\% of GPC first year students and 5\% of PST students think that they will be unsuccessful academically. 
Table 2. Distribution regarding the thoughts of the first-year students in GPC and PST Departments when they experience stress in the university lives

\begin{tabular}{lccccc}
\hline & \multicolumn{3}{c}{ GPC Department } & PST Department & \multirow{2}{*}{ Total } \\
\cline { 2 - 5 } & $\mathbf{F}$ & $\mathbf{\%}$ & $\mathbf{F}$ & $\mathbf{\%}$ & \\
\hline Thinking to fail lessons & 1 & $5 \%$ & 4 & $17 \%$ & 5 \\
\hline Thinking to be judged as ignorant by classmates and teachers & 13 & $62 \%$ & 12 & $50 \%$ & 25 \\
\hline $\begin{array}{l}\text { Thinking that the information to be learnt at university will not } \\
\text { be useful for the future life }\end{array}$ & 7 & $33 \%$ & 8 & $38 \%$ & 15 \\
\hline Total & 21 & $47 \%$ & 24 & $53 \%$ & 45 \\
\hline
\end{tabular}

Table 3. Distribution regarding the behaviours of the first-year students in GPC and PST Departments when they experience stress in the university lives

\begin{tabular}{|c|c|c|c|c|c|}
\hline & \multicolumn{2}{|c|}{ GPC Department } & \multicolumn{2}{|c|}{ PST Department } & \multirow{2}{*}{ Total } \\
\hline & $\mathbf{F}$ & $\%$ & $\mathbf{F}$ & $\%$ & \\
\hline Lack of desire to enter university environment & 11 & $42 \%$ & 7 & $36 \%$ & 18 \\
\hline Lack of desire to study & 4 & $15 \%$ & 2 & $11 \%$ & 6 \\
\hline Avoiding classes when unsuccessful & 2 & $8 \%$ & 3 & $16 \%$ & 5 \\
\hline Failure to develop social relationships with academics & 3 & $12 \%$ & 4 & $21 \%$ & 7 \\
\hline Failure to make new friends in university environment & 6 & $23 \%$ & 3 & $16 \%$ & 9 \\
\hline Total & 26 & $58 \%$ & 19 & $42 \%$ & 45 \\
\hline
\end{tabular}

No differences have been found between the opinions of GPC and PST students, the same view is being shared approximately and university first year students are afraid of being judged as ignorant in front of other individuals and they think that they will be evaluated as uninformed in minds of teachers.

\section{Findings Regarding the Behaviours of the First Year Students in GPC and PST Departments when They Experience Stress in the University Lives}

The research studied 45 participants in the context of determining the situations when the university students experience stress in their university lives. The answers given by students to the question "What are your behaviours regarding the situations in which you experience stress in your university life?" are as follows:

1. Lack of desire to enter university environment

2. Lack of desire to study

3. Avoiding classes

4. Failure to develop social relationships with academics

5. Failure to make new friends in university environment

The opinions of the participants were determined under the ratios and themes mentioned in Table 3 and the opinions given were presented. $42 \%$ of the GPC Department students stated that they exhibit behaviours such as lack of desire to enter the university environment and to avoid environments causing stress. "I feel bad when I go to the university. I want to return back to my high school. I do not want to go into the university environment, which does not make me feel good. This school is very big and difficult for me. When I enter a crowded social atmosphere, I want to get away from it immediately because I feel very anxious.”

The above opinions were provided by a student from the GPC Department. It can be said that behaviours of GPC first year students for avoiding environments which cause stress is in the foreground when this explanation and opinion percentage is considered. Despite that, \%36 of participants who are in position of PST department first year student stated that they intend to avoid university environment. \% 23 of GPC students and \%16 of PST students stated that intend to avoid adopting new behaviours, entering into a different circle of friends (cafeteria, photocopy centres, restaurants etc.). 
Table 4. Distribution regarding the situations that the first-year students in GPC and PST Departments expect to experience stress in their future professional lives

\begin{tabular}{|c|c|c|c|c|c|}
\hline & \multicolumn{2}{|c|}{ GPC Department } & \multicolumn{2}{|c|}{ PST Department } & \multirow{2}{*}{ Total } \\
\hline & $\mathbf{F}$ & $\%$ & $\mathbf{F}$ & $\%$ & \\
\hline Situations in which they have to perform career planning studies & 17 & $63 \%$ & 6 & $33 \%$ & 23 \\
\hline $\begin{array}{l}\text { Situations in which they have to fulfil their tasks successfully in the } \\
\text { profession }\end{array}$ & 10 & $37 \%$ & 12 & $67 \%$ & 22 \\
\hline Total & 27 & $60 \%$ & 18 & $40 \%$ & 45 \\
\hline
\end{tabular}

Regarding the question related with determination of behaviours in stressed situations in university life, $15 \%$ of GPC department first year students and 11\% of PST first year students stated that they do not want to study and demonstrate a behaviour of not fulfilling duties given to them. $8 \%$ of PST first year students stated that they avoid classes due to the fact that they do not want to be judged as unsuccessful when they do not complete given homework.

$12 \%$ of GPC department first year students stated that an internal and external social relationship cannot be developed with lecturers while $21 \%$ of PST department first year students have stated that a behaviour of developing relationship with lecturers inside and outside school cannot be demonstrated due to stress which is due to the university environment.

It is seen that no differences have been observed between the opinions of GPC and PST students, the same view is being shared approximately and behaviours such as avoiding the environment due to the stress, not studying, avoiding crowded places, avoiding classes or courses when duties are not fulfilled, inability to develop social relationships with lecturers and inability to make new friendships in the university environment are demonstrated by them in terms of at the determination of situations which the stress is experienced in university life.

\section{Findings Regarding the Situations that the First Year Students in GPC and PST Departments Expect to Experience Stress in their Future Professional Lives}

45 participants were included in the study in determining the situations that university students experience stress in the university life. The answers given by students to the question "What are the situations that you expect to experience stress in your future professional life?" are as follows:

1. Situations in which they have to perform career planning studies

2. Situations in which they have to fulfil their tasks successfully in the profession

The opinions of the participants were determined under the ratios and themes mentioned in Table 4 above and the opinions given were presented. $37 \%$ of first-year GPC students and $67 \%$ of first-year PST students indicated that they could experience intense stress in situations where they had to successfully accomplish a task in the profession. "Will I be able to perform my job well when I become a guide or psychological counsellor at a private institute? Will I be successful in my profession? I hope everything goes well. Even thinking about these situations put me under stress. The above opinions were provided by a student from the PST Department. On the basis of this explanation and opinion percentage, it can be said that the fact that the first-year students studying in the GPC and PST Departments think that they may experience stress in the case of successfully performing their profession as teachers is on the foreground.

Regarding the question on the students' thoughts on the stress to be experienced in the future professional life, $67 \%$ of the first-year students in GPC Department and 33\% of the first year students in PST Department stated that they could experience stress in case of doing career planning.

Regarding the determination of situations in which the stress will be experienced in their future profession lives, it is understood from the views that there are no differences between views of PGC and PST students, the 
same view is being shared approximately and there is a thought that stress can be experienced at the situations like conducting career planning studies and at the situations like there is need for fulling duties successfully at their professions.

\section{RESULTS AND DISCUSSION}

In the context of determining the situations in which university students experience stress, no differences have been found among the opinions of the first-year students studying in the Counselling and Psychological Guidance and Preschool Teaching Department, they share similar opinions and they experience stress in case of adapting to the university environment, family estrangement, failure to find expectations from university environment and abandonment of past habits. This finding is similar to the study conducted by Dyson \& Renk (2006) on determining the situations in which university students experience stress. Dyson \& Renk (2006) indicated that university students experience stress in adapting to the academic life and university and in the social problems they have with family and friends. In this context, it can be said that university students experience stress in case of adapting to the university environment, family estrangement, failure to find expectations from university environment and abandonment of past habits.

In the study of Doğan \& Eser (2013), they stated that new university students experience stress when they are expected to perform career planning while trying to adapt to the new environment, to establish new friendships during the family estrangement as well as successfully achieving their degrees and fulfilling their responsibilities as expected from them as a necessity of the university life. Moreover, they explained that students exhibit behaviours such as inability to study, to make friends, to fail modules and to establish relationships with academics.

Along with the finding of determination of thoughts about situations in which stress is experienced and they have negative thoughts like students will be unsuccessful at the courses and assessed as uninformed in front of classmates and lecturers, situations that are thought to cause stress in the future profession lives are determined as conducting profession planning studies and inability of fulfilling duties. In a similar study which was conducted by Aşçı, Hazar, Kılıç \& Korkmaz (2015), it was determined that stress is caused by negative thoughts like becoming unsuccessful, the situation that lectures are not sufficient and are not understandable, lack of knowing what to do after graduation, being afraid of inability of finding jobs and lack of professional information.

Ardıç explained in the study conducted in 2009 that is named as effects causing stress and coping behaviours that behaviours such as avoiding school, lack of minding classes and breaking hearts of friends and lecturers are shown by students in situations in which stress is experienced. This result has evoked the findings that GPC and PST students demonstrate behaviours such as lack of desire to enter university environment, avoiding from studying, avoiding courses, lack of developing social relationships with lecturers and inability to make new friendships in the university environment, which have been emphasized in the finding of the determination of behaviours while stress is being experienced in university life.

(Güçlü, 2001; Deniz \&Yılmaz 2005; Durna, 2006; Gizir, 2005; Avşaroğlu \& Üre 2007) stated that the main sources of stress for university students are adapting to new school, academic and social environment and coping with meeting the expectations while it is unavoidable to experience stress against these situations. At the same time, they explained that the problem that students have experienced about establishing relationships in the new environment to which they intend to adapt leads to stress on students. In this context, it can be said that university students experience stress in adapting to the new university environment and establishing new relationships.

Having examined the obtained findings, it has been found out that new university students experience a certain level of stress in the situations of adapting to new university environment, making new friends, coping with family estrangement and negative thoughts such as failure and making career planning.

This view is observed to be in accordance with the research findings of Akbağ, Sayiner \& Sözen (2005. In the research of Akbağ, Sayıner \& Sözen (2005), it has been stated that the sources of stress of university students were excessive anxiety, inability to adapt to the environmental conditions, avoiding to establish relationships with 
other individuals, avoidance and uncertain fears and thoughts. These findings are observed to be generally in accordance with the findings of other research (Hannigan, Edwardas, Burnard, \& Philip, 2004; Keegan, 2003, Bulut, 2005) in the discussion process.

\section{REFERENCES}

Akbağ, M., Sayıner, B., \& Sözen, D. (2005) Üniversite Öğrencilerinde Stres Düzeyi, Denetim Odağ1 ve Depresyon Düzeyi Arasındaki İlişki Üzerine Bir İnceleme. M.Ü. Atatürk Ĕ̆itim Fakültesi Eğitim Bilimleri Dergisi, 21, 5974.

Ardıç, A. (2009). Öğrencilerde Strese Neden Olan Etkenler ve Başa Çıkma Davranışları. T.C. Milli Eğitim Bakanlığı, Eğitim Araştırma ve Geliştirme Dairesi Başkanlığı, Ankara.

Aşçı, Ö., Hazar, G., Kılıç, G., \& Korkmaz, A. (2015). Üniversite Öğrencilerinde Stres Nedenlerinin ve Stresle Başa Çıkma Biçimlerinin Belirlenmesi. Uşak Üniversitesi Sosyal Bilimler Dergisi, 5(4), 215-221.

Avşaroğlu, S., \& Üre, Ö. (2007). Üniversite Öğrencilerinin Karar Vermede Özsaygı, Karar Vermede Özsaygı, Karar Verme ve Stresle Başaçıkma Stillerinin Benlik Saygısı ve Bazı Değişken Açısından İncelenmesi. Selçuk Üniversitesi Sosyal Bilimler Enstitüsü Dergisi, 18, 85-100.

Bulut, N. (2005). İlköğretim öğretmenlerinde, stres yaratan yaşam olayları ve stresle başa çıkma tarzlarının çeşitli değişkenlerle ilişkisi. Kastamonu Ĕ̆itim Dergisi, 13(2), 467-478.

Deniz, M. E., \& Yılmaz, E. (2005). Üniversite Öğrencilerinde Duygusal Zeka ve Stresle Başa Çıkma Stilleri Arasındaki İlişkinin İncelenmesi. Türk Psikolojik Danışma ve Rehberlik Dergisi, 25, 17-26.

Doğan, E., \& Eser, M. (2013). Üniversite Öğrencilerinin Stresle Başa Çıkma Yöntemleri: Nazilli MYO Örneği. Electronic Journal of Vocational Colleges, 3(4), 32-38.

Durda, U. (2006). Üniversite Öğrencilerinin Stres Düzeylerinin Bazı Değişkenler Açısından İncelenmesi. İktisadi ve İdari Bilimler Dergisi, 20(1), 320-343.

Dyson, R., \& Renk, K. (2006). Freshmen Adaptation to University Life: Depressive Symptoms, Stress and Coping. Journal of Clinical Psychology, 62(10), 1231-1244.

Gizir, C. A. (2005). Orta Doğu Teknik Üniversitesi Son Sınıf Öğrencilerinin Problemleri Üzeri bir çalışma. Mersin Üniversitesi Ĕ̆itim Fakültesi Dergisi, 1(2), 196-213.

Güçlü, N. (2001). Stres Yönetimi. Gazi Üniversitesi Gazi Ĕ̆itim Fakültesi Dergisi, 21, 91-109.

Hannigan, B., Edwards, D., \& Burnard, P. (2004). Stress and Stress Management in Clinical Psychology: Findings from a Systematic Review. Journal of Mental Health, June, 13(3), 236245.

Keegan, L. (2003). Modalities for Managing Stress and Anxiety. Critical Care Nurse, 23(3), 5558.

Rojas, V. M., \& Kleiner, B. H. (2000). The Art and Science of Effective Stress Management. Management Research News, 23, 103-106.

\section{http://www.ejmste.com}

